\title{
Community Empowerment on Establishment of Friendly-Village for Women and Children
}

Series of Agendas on Legal Protection and Community Empowerment in Bandungan Sub-District, Bandungan District, Semarang Regency

Sarno Setiawan ${ }^{1 *}$, Muhammad Afis Saifunuha ${ }^{2}$, Jauza Lasta Kautsar ${ }^{3}$, Cahya Wulandari ${ }^{4}$

${ }^{1}$ Department of Chemistry, Faculty of Mathematics and Natural Sciences, Universitas Negeri Semarang, Indonesia 2,3,4 Faculty of Law, Universitas Negeri Semarang, Indonesia *Corresponding Author: S. Setiawan, email: sarno.setiawan19@gmail.com

\begin{abstract}
Worthy children and women's Village/Sub-district is a village/sub-district development that brings together the commitment and resources of village/village government that involve the community and business world in the sub-district in order to promote, protect, Fulfilling and respecting the rights of children and women, which are planned consciously and sustainably. Some laws have been established to support the protection of children and women such as the Act of the Republic of Indonesia number 35 year 2014 about the amendment to law Number 23 year 2002 about protection Children and Law Number 23 year 2004 concerning the elimination of violence in households. In order to realize the child and women's friendly villages, there are several efforts that can be done as the socialization of legal protection and community empowerment. Socialization programs not only provide information or knowledge but also supported by the empowerment of community that provides training and experience in the community. So that socialization tends to only provide information to be easier to understand by the community through the Community Empowerment program and increase public awareness to continue to actively participate in the realization of child and women's friendly villages.
\end{abstract}

Keywords: Child and Women's Friendly Villages; Community Empowerment; Legal Protection; Socialization

\section{How to cite:}

Setiawan, S., Saifunuha, M.A., Kautsar, J.L., \& Wulandari, C. 'Community Empowerment on Establishment of Friendly-Village for Women and Children'. Indonesian Journal of Advocacy and Legal Services, 1(1), 5-22. DOI: 10.15294/ijals.v1i1.33756 


\section{A. Introduction}

Children and women's friendly-village/Sub-district is a village/sub-district development that brings together the commitment and resources of village/village government that involve the community and business world in the sub-district in order to promote, protect, Fulfilling and respecting the rights of children and women, which are planned consciously and sustainably.

Cases of violence against women and children in Indonesia have increased significantly each year. The form is not only physical violence, but also psychological, sexual, neglect and exploitation. Perpetrators are not just outsiders, even people from the immediate environment. This fact makes us realize that a massive effort is needed to make prevention through community movements in order to create safe and comfortable environmental conditions for women and children. ${ }^{1}$

Based on data from the Indonesian Child Protection Commission (KPAI) in 2018 there were 4,885 cases. $^{2}$ The case of children dealing with the law ranks first, namely 1,434 cases, followed by cases related to family and child care as many as 857 cases. In addition, based on government data assisted by the United Nations Population Fund (UNFPA) in March 2017, reported that a third of the Indonesian female population had experienced sexual and physical violence. ${ }^{3}$ Based on this, it is important to build a friendly-village for child and women.

The aims and objectives of children and women's friendly-villages development:

1. To increase the awareness and concrete efforts of village/sub-district officials, families, communities and businesses in the region in an effort to build a friendly-village for child and women that ensures the fulfillment of the rights of children and women.

$1 \quad$ Redaksi WE Online, "Sepanjang 2017, Kasus Kekerasan Terhadap Perempuan dan Anak Terus Meningkat" (https://www.wartaekonomi.co.id/read165375/sepanjang2017-kasus-kekerasan-terhadap-perempuan-dan-anak-terus-meningkat.html, accessed on 29 August 2019, 13.00 WIB).

2 Widyanuratikah, Inas \& Ratna Puspita, "KPAI Terima Pengaduan 4.885 Kasus Anak Selama 2018" (https://www.republika.co.id/berita/nasional/umum/19/01/08/pl0dj1428kpai-terima-pengaduan-4885-kasus-anak-selama-2018, accessed on 29 August 2019, 13.17 WIB).

$3 \quad$ Hamid, Usman. "Bagaimana menguatkan perlindungan perempuan? Perkuat peran Komnas Perempuan” https://theconversation.com/bagaimana-menguatkanperlindungan-perempuan-perkuat-peran-komnas-perempuan-112797; Juliana, R. \& Arifin, R. (2019). 'Anak dan Kejahatan (Faktor Penyebab dan Perlindungan Hukum)'. Jurnal Selat, 6(2), pp. 225-234; Arifin, R., \& Lestari, L.E. (2019). 'Penegakan dan Perlindungan Hak Asasi Manusia di Indonesia dalam Konteks Implementasi Sila Kemanusiaan yang Adil dan Beradab'. Jurnal Komunikasi Hukum (JKH), 5(2), 12-25. 
2. To ensure that in children and women's friendly-villages development, taking into account the needs, aspirations, the best interests of children and not discrimination against children and women.

3. To unite the potential and realization of human resources, natural resources, sources of funds, facilities, infrastructure, methods and technology that exist in the village/sub-district, community participation and the business world in the village/sub-district in an effort to fulfill the rights of children and women.

Concrete efforts in the development of Child and Women's Friendly Villages carried out by UNNES KKN Team are one of them by conducting socialization to children and women. Some of the work programs that we have carried out are the Child Protection Socialization Program on Antibullying, RUMPI (Smart Home), Sex Education Sozialization Program (Child Protection on Sex Education), Socialization of Legal Protection for Children, August 17th Competition (LOTUS) in which we are instill the values of nationalism and the Socialization of the Importance of Handwashing and Toothbrushes intended for children. While the work programs that we have carried out to realize legal protection against women and support community empowerment, especially for women, are the Socialization of Women Reaching Dreams and Aspiration (SOPER CINTA), Creation of Washing Soap (KUNCI), and Socialization of Legal Protection for Women. Besides that, the UNNES KKN Team also established a Legal Aid Center (POSBANKUM) located at the Bandungan Village Office, Bandungan District, Semarang Regency. The Legal Aid Post (POSBANKUM) seeks to capture legal issues in the Bandungan District. In the 43 days of the KKN in Bandungan Village, we found several legal problems that occurred such as divorce and land disputes. Even though we as representatives of the Legal Studies and Legal Aid Center (PKBH) of the Law Faculty of Semarang State University cannot assist until the judicial process, but at least we take part in preparing the files needed.

One effort to realize the Child and Women's Friendly-Village is to hold a socialization program on Legal Protection for Children and Women. The program is held on Wednesday, August 14, 2019. The program presented speakers namely Cahya Wulandari, S.H., M.Hum as our Suprevisor (Dosen Pembimbing Lapangan, DPL) who currently serves as Chair of the Law Protection Clinic for Women and Children of the Faculty of Law UNNES as a speaker. The program aims to provide knowledge about acts that include crimes against children and women. The material presented was entitled "The Participation of the Legal Clinic for the Protection of Women and Children in the Prevention of Violence Against 
Women and Children in the Community" which in this case is expected to provide knowledge and insight to the community especially women and children to be able to protect themselves. In addition to supporting the realization of Child and Women's Friendly-Village, the UNNES KKN Team also empowered the community.

Community empowerment is the concept of economic development that encapsulates the values of the community to build a new paradigm in people centered, participatory, empower-ment and sustainable development (Noor, 2011). The implementation of community empowerment aims to mobilize greater community participate-on for activities that they do themselves. Thus it becomes a very important task for development management to mobilize, guide, create climate that supports development activities carried out by the community. These efforts are carried out through government policies, regulations and development activities aimed at supporting, stimulating and paving the way for community development activities.

The Government's policy on community empowerment is explicitly stated in the GBHN of 1999 and Law Number 32 of 2004 about Regional Government. In the 1999 GBHN, specifically in the Direction of Regional Development Policy, it was stated among others "Developing regional autonomy in a broad, tangible and responsible manner in the context of community empowerment, economic institutions, political institutions, legal institutions, religious institutions, custom and non-governmental organizations, community as well as all the potentials of the community in the Republic of Indonesia". This is reinforced by Law No. 22/1999 on Regional Government, among others it is emphasized that the basic things in this law are to encourage people to empower, develop initiatives and creativity, and increase community participation.

The discussion is in accordance with the concept of community participation, one of which can refer to the opinion of Mikkelsen (Rukminto, 2008) that participation is community involvement in efforts to develop the environment, life and themselves. ${ }^{4}$

Yulianti (2012) explained that there are several factors that influence the community for the participation process, one of which is the work of the community. Usually people with a certain level of work will be able to spend more or not even take the time to participate in a particular project. Often the fundamental reason for society is the conflict between commitment to work and the desire to participate.

4 Rukminto, A. I. (2008). Intervensi Komunitas: Pengembangan Masyarakat Sebagai Upaya Pemberdayaan Masyarakat. Jakarta: PT Grafindo Persada. 
Increasing community participate-on in an activity can be done by procuring an activity by the community itself or other parties. Students who are part of the community must also participate in increasing community participation. This is in accordance with the Law of the Republic of Indonesia Number 20 of 2003 about the national education system article 20 paragraph 2 which states that "Higher education is obliged to carry out education, research, and community service". The three aspects of the tri dharma of higher education are carried out in balanced, harmonious and integrated proportions. It aims to produce people who have adequate knowledge in their respective fields, and are able to conduct research, and are willing to devote themselves to the nation and state. Students who are basically subjects or actors in the national and national renewal movements are expected to be able to contribute to community development (Perdana et al., 2013).

One form of community service is the KKN program. Bandungan Village is one of the villages located in Bandungan District, Semarang Regency. This sub-district is one of the areas used as the location of KKN. This village is bordered by several other villages, such as the east with Jetis Village, the south with Kenteng Village, the north with Duren Village, and the west with Bandungan Village. The occupations of the majority population are farmers, civil servants and traders. This is in accordance with the demographic situation of the Bandungan sub-district which consists of flower and vegetable plantations. Educational facilities consist of 2 Early Childhood Education Programs, 3 kindergartens, and 4 elementary schools.

Bandungan Village consists of 7 RWs/Area namely Bandungan (RW/Area 01), Gamasan (RW/Area 02), Pendem (RW/Area 03), Junggul (RW/Area 04), Gintungan (RW/Area 05), Piyoto (RW/Area 06), Bandungan (RW/Area 07). On this occasion, UNNES KKN Team Post was placed in the Pendem Area. Pendem area has residents who are less active in participating to participate in activities both organized by the village and youth clubs. One of the factors causing the lack of community participation in Pendem is caused by people's busyness, namely farming and trading. This not only impacts on the lack of community participation but also on their children who do not get time with parents. Therefore, the UNNES KKN Team conducted several work programs to increase the participation of the Pendem community in participating in the work program. 


\section{B. Method}

The work program of UNNES KKN Team is realized in a number of steps, including the preparation, implementation, and evaluation stages. The preparation phase is carried out by conducting a site survey, problem analysis, and coordination with the Bandungan Sub-district.

The implementation phase is carried out with two methods: lecture and practice. ${ }^{5}$ The program implementation phase is set within a period of 45 days, the work programs include: RUMPI (Smart Home), SOPER CINTA (Women Reaching Dreams and Aspiration Socialization), Plangization, LOTUS (August 17th Competition), SENJA (Healthy Friday Gymnastics), KUNCI (Washing Soap Creations), Minggu Bersih (Sunday Green), Sex Education Sozialization Program (Child Protection on Sex Education), POSBANKUM (Legal Aid Center), Legal Protection Socialization for Women and Children, and Child Protection Socialization Program on Anti-bullying aimed at elementary school children. The evaluation phase is carried out with the aim to discuss the results that have been achieved from the implementation of the work program. The process of collecting data is done by interviews, interviews, and documentation. The model and concept scheme for empowerment are illustrated in Figure $1 .{ }^{6}$

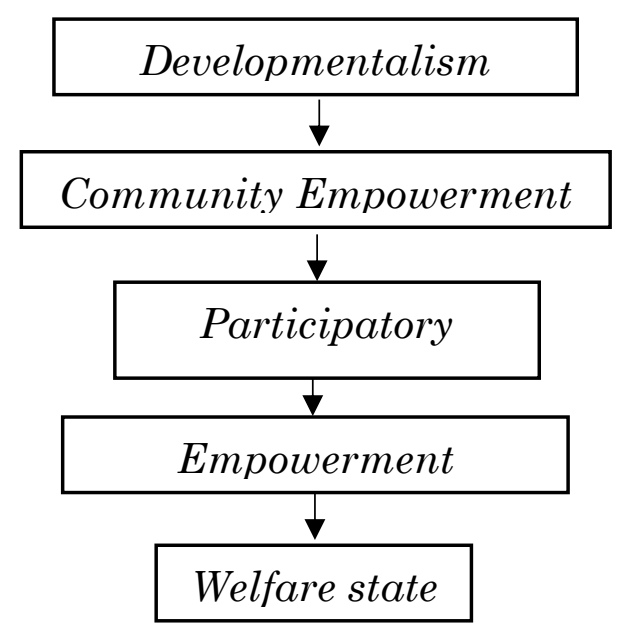

Figure 1. The Theoretical Framework of Community Empowerment

$5 \quad$ Sanjaya, W. (2010). Strategi Pembelajaran Berorientasi Standar Proses Pendidikan. Jakarta: Kencana.

6 Hilman, Y. A. dan Elok, P. N. (2018). Model Program Pemberdayaan Masyarakat Desa Berbasis Komunitas. Sosial Politik Humaniora. 6(1): 45-67. 


\section{Result and Discussion}

Ministry of Women Empowerment and Child Protection Regulation of the Republic of Indonesia Number 11 of 2011 explains the definition of ChildFriendly City (Kota Layak Anak, hereinafter called as KLA) is a child rights-based development system through the integration of commitment and resources of the government, community and business world that is planned thoroughly and sustainably in policies, programs and activities to guarantee the fulfillment of rights. To create a good environment, Linda said that the institution she led had issued Ministerial Regulation No. 6 of 2013 about Implementation of Family Development and also a policy towards a KLA. The policy objectives towards child friendly-villages include building a more integrated and sustainable child development system in the district/regency, so that the acceleration of the fulfillment of children's rights can be immediately carried out by all parties. ${ }^{7}$

The community of Pendem majority work as a flower farmer. The flowers are produced for sale in Bandungan Market, distributed to the city of Semarang, as well as orders from others. The average community worked from morning to afternoon, then in the early morning began to work again to sell the flowers. This is what leads to reduced community participation due to busy work.

Understanding of this problem for community empowerment requires a subjective attitude that departs from the basic attitude that every social research is always carried out to improve the existing social situation rather than merely describing and explaining the reality (Noor, 2011). Based on the work program from the KKN team, the Community participated actively in the implementation of the work program. The types of work programs are as follows:

1. Community Empowernment Programs on Establishing of Friendly-Village for Women and Children

a. Smart Home (RUMPI)

RUMPI is a work program that gives children a space to learn. The learning activities include do a school homeworks, drawing, and dancing. The "RUMPI" Program is conducted daily, from Monday to Friday it is used to study, while on Saturdays and Sundays it is used to conduct games that are educating. These games are Ludo, Congklak, Jumping rope and Bekel

Peraturan Kementrian Negara Pemberdayaan Perempuan dan Perlindungan Anak Republik Indonesia Nomor 11 Tahun 2011 (Tentang Kebijakan/Pengembangan Kota Layak Anak). 
ball and at the end of the program we hold hand washing and toothbrush together. The results show that children are enthusiastic in following the RUMPI program so that they better understand the subject matter taught in the school. After we introduce that program, not only local people but many students from other village as from the Bandungan 01 State Elementary School.

\section{b. Dreams and Aspiration of Indonesian Women Socialization (SOPER CINTA)}

The Program is held on Wednesday, August 14, 2019. Implementation of this program aims to inspire mothers in Bandungan Village through seminar activities. This activity presents the female speakers who have been successful entrepreneurial, namely Ita Yulicha, S.E. Speaker in this program is a businesswoman accessories batik and craft is known as "Yulicha Accessories Branded and craft". The purpose of our program to local women here to spot local women here to be a entrepreneur. The results achieved that the participants were very enthusiastic, this is shown at the time of the question and answer session, many of the participants who asked. In addition, many registered participants have a business to consult their entrepreneurial sustainability.

\section{c. August 17th Games (LOTUS)}

This Program is done by organizing activities in the form of competitions that educate with the theme of nationalism and patriotism in cooperation with the Pendem Village Youth Association. The competition is not only followed by children, but also includes fathers and mothers. This type of games is a stocking, futsal race and a trail for children, football for fathers, line of march (PBB), chorus and decorating Tumpeng for mothers. The competition is held on 2-16 August 2019. The result for sport and spirit for the community here especially in the Pendem Area. They are very happy welcoming this competition, we can see from their well preparation. Line of march (PBB), choir, and decoration cone-tiled rice cakes competition is a type of competition that require longer preparation than other types of competition. However, mothers are enthusiastic in preparing the competition, for example every afternoon they exercise in each RT (smallest part of village) by inviting KKN students to accompany the train. The existence of this event can increase the participation of the community in following the activities of the event that has been held. The activities of this program shown as on Figure 2. 

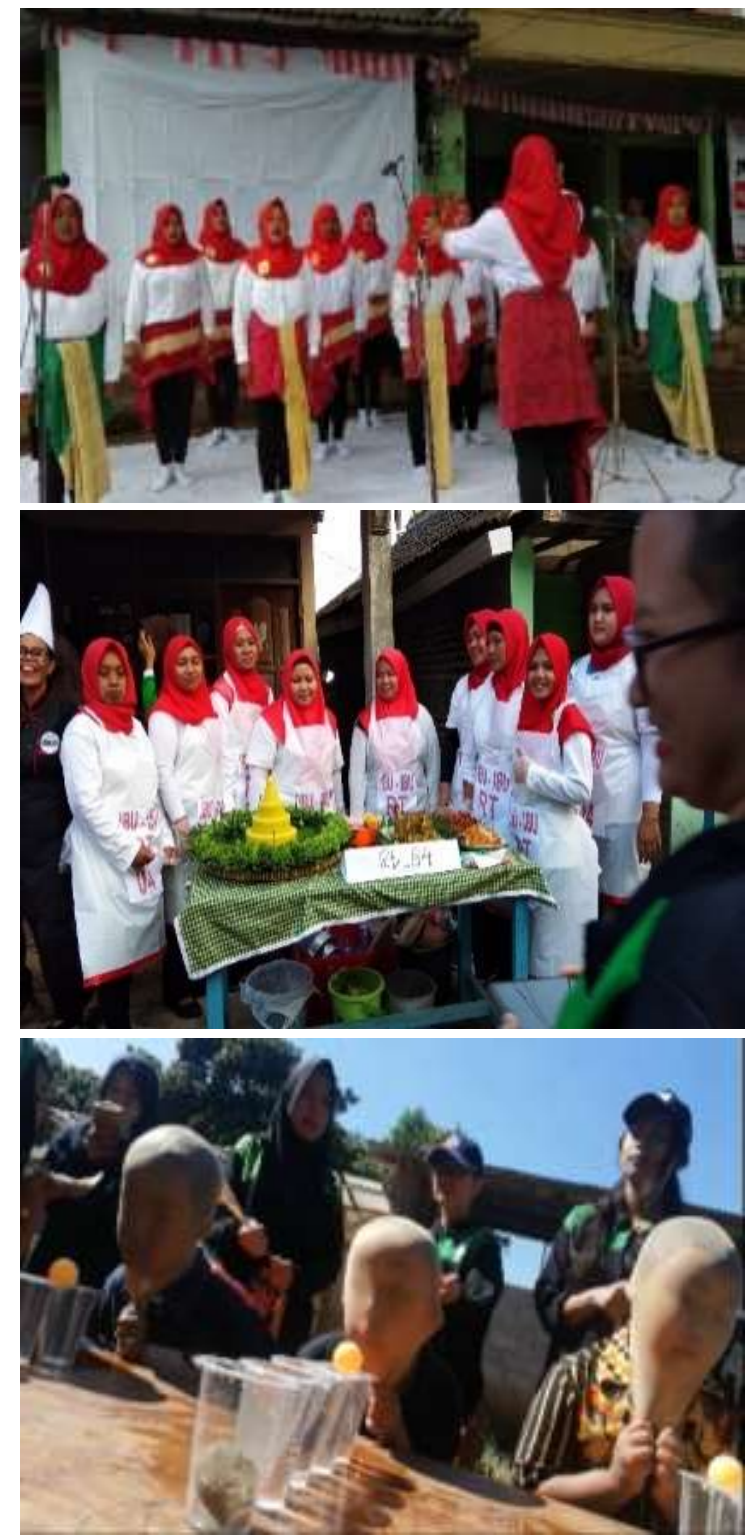
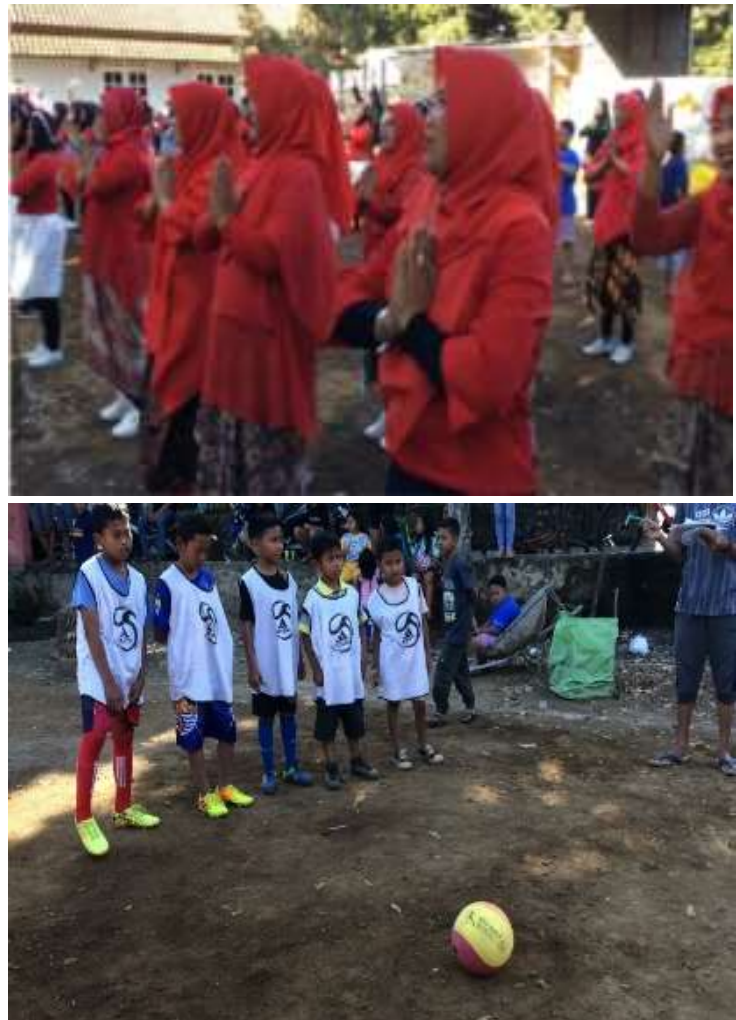

Figure 2. Documentation of August $17^{\text {th }}$ Competition activities. Source: Personal documents, August 10-12 th 2019

d. Healthy Friday Gymnastics (SENJA)

This program aims to invite them healthy life with gymnastics. UNNES KKN Team ask the community of Pendem Area to life healthy with sports, because community here is careless in keeping healthy. This program is held on every Friday at 3.30 p.m. The community here give a good response to our program. By doing exercise regularly will make your health and physical development good and balanced physically and spiritually.

\section{e. Washing Soap Creations (KUNCI)}

The "KUNCI" program is a training activity for making dish soap for mothers in Pendem area. It starts by teaching housewives in the Pendem area through training in making Washing Soap Creations (KUNCI). The purpose of this program is to give the knowledge and chance to do 
entrepreneur. This program is also one of the programs to support community empowerment. The "KUNCI" program is held on Thursday, August 15, 2019. The results now mothers in here can make washing soap with various scents and colors and are very enthusiastic to make dish soap with other innovations. We want mothers here make this training as one of business opportunity.

\section{f. Socialization of the Importance of Handwashing and Toothbrushes}

The implementation of this program to make early childhood children with an understanding of the importance of hand washing and toothbrushes. This program is held on 2 and 20 August 2019 at YPI ArRisalah and PAUD PUTRA MULIA. The results for people here they do understand how to wash hand and toothbrushing and can practice it directly after being taught by UNNES KKN Team. During the activity, the children were very enthusiastic in washing their hands and toothbrushes according to the stages directed by the KKN Team. It is expected that from this activity children can maintain a healthy lifestyle and practice it in everyday life.

\section{g. Sunday Green (Minggu Bersih)}

This program is giving knowledge to maintain environmental cleanliness. This program is a form of invitation to the community so that each individual can move together to be more concerned about environmental cleanliness. The background to this program is that there are a lot of poorly maintained prayer rooms. Besides the placement of the mosque is less strategic because it is close to the mosque, so people prefer to go to the mosque. Related to this the impact on the mosque which cleanliness is less concerned. This program is held on every Sunday at 7-9 a.m. at the Prayer room around Pendem area. The results increased awareness of the local community so that they could live healthy and clean and pay more attention to the cleanliness of the Prayer room around Pendem. It is expected that after the UNNES KKN Team has finished the KKN Program, the community will be able to jointly continue these activities so that the cleanliness of the Prayer room around Pendem area will continue to be maintained.

\section{h. Sex Education and Child Protection Socialization Program}

Sex education program is an introduction to sex education programs for children. Sex education equips students to have sexual behaviors that are in accordance with applicable values and norms and avoid forms of 
sexual harassment. ${ }^{8}$ The phenomenon of sexual harassment has increasingly become the background of the KKN UNNES Team to carry out the "Sex Education" Child Protection Socialization program. The program begins by providing understanding and knowledge to children about matters that can be directed as sexual harassment, including what body parts may or may not be touched, how to deal with sexual harassment and other matters relating to "Sex Education "which of course the material provided can be easily understood by children. This program was held on Wednesday, August 14, 2019 in Bandungan 03 Elementary School, which was attended by 3rd grade students. The results achieved are increasing children's knowledge about sex education that can be used as self-protection. This is very important for them to know if one day something unexpected happens.

\section{i. Legal Aid Center (POSBANKUM)}

Posbankum is a program that aims to help problems experienced by the community relating to the law. ${ }^{9}$ This program is carried out at the Bandungan Village Office. The method we use is that every time there are activities that involve Bandungan sub-district community, we will socialize the existence of a Legal Aid Post located at the Bandungan Village Office. Assistance in solving problems related to correspondence, for example letters of introduction to marriage, divorce, land disputes, persecution, death certificates, resettlement, and birth certificates. The program is carried out every working day (Monday-Friday) by establishing a legal aid post at the Bandungan Village Office. The results achieved are able to help solve problems related to the law experienced by the Bandungan sub-district community.

\section{j. Socialization of Legal Protection for Women and Children}

The program was carried out on Wednesday, August 14, 2019 in conjunction with the Socialization of Women Achieve Dreams and Ideals (SOPER CINTA) program. This program presents speakers namely Cahya Wulandari, S.H., M.Hum. as our Lecturer who currently serves as Chair of the Legal Protection Clinic for Women and Children at the Faculty of Law UNNES. The program aims to provide knowledge about acts that include crimes against children and women. The material presented was entitled "The Participation of the Legal Clinic for the Protection of Women and

$8 \quad$ Muntamah, A.L., Latifiani, D., \& Arifin, R. (2019). 'Pernikahan Dini Di Indonesia: Faktor dan Peran Pemerintah (Perspektif Penegakan dan Perlindungan Hukum Bagi Anak)'. Widya Yuridika 2 (1), 1-12; Kemala Dewi, M., \& Arifin, R. (2019). Emancipation and Legal Justice; Portrait of Women's Legal Protection In Indonesia. Jurnal Cita Hukum, 7(1), 101-114.

$9 \quad$ Angga, A., \& Arifin, R. (2019). 'Penerapan Bantuan Hukum Bagi Masyarakat Kurang Mampu di Indonesia' DIVERSI: Jurnal Hukum 4 (2), 218-236. 
Children in the Prevention of Violence Against Women and Children in the Community" which in this case is expected to provide knowledge and insight to the community especially women and children to be able to protect themselves. The result achieved is that the community is more aware of actions that include crime, especially domestic violence.

k. Anti-Bullying and Child Protection Socialization Program

This program aims to provide knowledge about bullying which includes acts that include bullying, types of bullying, and the impact of bullying on victims. Bullying or violence is behavior where the offender wants his victims to be hurt both physically and mentally. The phenomenon of violence often occurs among children and adolescents. ${ }^{10}$ That was the background of the KKN UNNES Team to implement the Anti-Bullying Child Protection Socialization program. This program is carried out by giving understanding and knowledge to children from an early age that the impact of bullying is not only physical, but also mental and psychological victims who do not rule out the possibility of death. This program was held on Wednesday, July 24, 2019 at Bandungan 01 Elementary School, which was attended by 6 th grade students with 84 students. The results achieved are increasing children's knowledge about the dangers of committing bullying and making students have good personalities.

\section{Evaluation of Programs and Analysis}

Evaluation of community empowerment activities in Pendem Area, Bandungan sub-district was conducted using the Participatory Rural Appraisal (PRA) method. The use of this concept is based on community involvement in all activities by putting pressure on participation with the principle of learning from the community, outsiders as facilitators, communities as actors, mutual learning and sharing experiences, the involvement of all community groups. ${ }^{11}$

10 Andhini, A.S.D., \& Arifin, R. (2019). 'Analisis Perlindungan Hukum Terhadap Tindak Kekerasan pada Anak di Indonesia'. Ajudikasi: Jurnal Ilmu Hukum 3 (1), 41-52; Arifin, R., Widyawati, A., Rasdi, R., Wicaksono, S. S., \& Maskur, M. A. (2019). 'Penguatan Kapasitas Hukum Bagi Orang Tua Siswa dan Guru di Desa Kalisegoro Semarang dalam Rangka Peningkatan Kesadaran Tanggungjawab Pendidikan Bersama (Sebuah Pengabdian Pendekatan Hak Asasi Manusia'. Jurnal Pengabdian Hukum Indonesia (Indonesian Journal of Legal Community Engagement) JPHI, 1(2), 158-171; Setyaningrum, A., Arifin, R. (2019). 'Analisis Upaya Perlindungan dan Pemulihan Terhadap Korban Kekerasan dalam Rumah Tangga (KDRT) Khususnya Anak-Anak dan Perempuan'. JURNAL MUQODDIMAH: Jurnal Ilmu Sosial, Politik dan Hummaniora 3 (1), 9-19.

Noor, M. (2011). Pemberdayaan Masyarakat. Jurnal Ilmiah CIVIS. 1(2): 87-99. 
The involvement of the Bandungan Sub-district community, especially the Pendem area in several work programs that have been carried out shows an active participation attitude. This is shown in various activities such as soccer between RTs for fathers, line of march competitions, choirs, and decorating cone-tiled rice cakes for mothers, PES competitions for all groups, and stockings, futsal, dance, and trail searches for children. Not only in competition activities, other activities of the community also play an active role such as the socialization of women reaching their dreams and aspiration (SOPER CINTA), the socialization of legal protection for women and children, and the evaluation of the PKK work program in Bandungan Sub-district. In addition, smart home activities for children as well as training in making washing soap (KUNCI) for Pendem area mothers were also very enthusiastic in participating in the program.

Community participation in each activity shows the development towards community independence. Important points of community independence can be seen as a condition that is formed through the collective behavior of people to make social changes. The sustainability of collective behavior change is supported through community intervention programs developed by outside parties (government, KKN students) or on the basis of initiative and creativity of the local community. ${ }^{12}$

In this case, conceptually it is important to understand the characteristics of the community development management components so that they have a close cooperative relationship in providing complementary ideas, ideas, support, assistance. Illustration of the concept is shown in Figure 4.

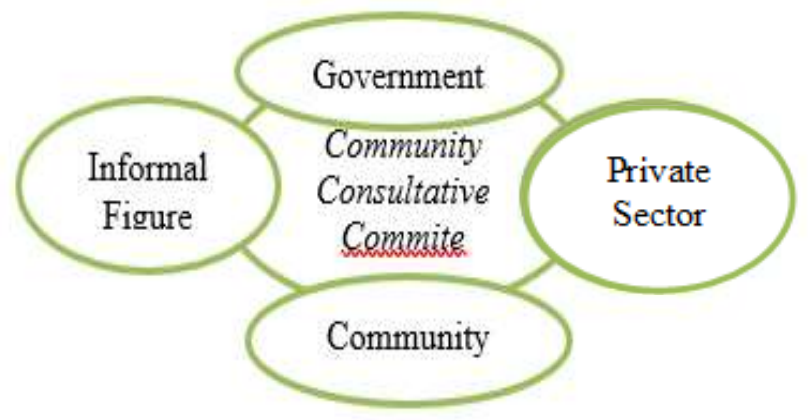

Figure 3. Relationship between core components of community development managers. Source: Dumasari, 2014.

The illustration shows the involvement and contribution of all relevant stakeholders such as government, private sector, non-governmental

12 Puspitasari, D. C. (2015). Wirausaha Muda membangun Desa: Dinamika Partisipasi Pembangunan Desa. Jurnal Studi Pemuda. 4(2): 330-341. 
organizations (NGOs) and the community are important in the process of village community development and development process. Each institutional component (commonly referred to as stakeholder) has its own role and function which therefore needs to be regulated and agreed upon so that it becomes a synergistic effort that mutually reinforces one another. The functioning of the network between institutions can indicate the level of interaction that shows commitment, involvement and the level of bonding that will be built between network partners (Puspitasari, 2016).

Community empowerment can place the community in a strong position in daily life. The position is not as beneficiaries that can make the community become dependent, but the position that should be a subject (agent or participant who acts) that moves collectively to achieve independence. However, being independent does not necessarily mean that the state takes its hands off, but is still needed, especially in a number of fields, which are the responsibility of the state, such as the provision of public services (health, education, housing, transportation and so on) to the public, of course, are the duty of the state. Independent community as a participant means opening up space and capacity to develop creative potential, control the environment and its own resources, solve problems independently, and participate in determining the political process in the realm of the state. The community participates in the development process and governance. ${ }^{13}$

\section{Conclusion}

Some programs as an effort to realize the Child and Women's Friendly Villages in Bandungan Sub-district include 11 work programs, called: Smart Home (RUMPI), Women Reaching Dreams and Aspiration Socialization (SOPER CINTA), August 17th Competition (LOTUS), Gymnastics Healthy Friday (SENJA), Washing Soap Creation (KUNCI), Socialization on the Importance of Handwashing and Toothbrushes, Sunday Green, Sex Education Child Protection Socialization Program, Legal Aid Center (POSBANKUM), Socialization of Legal Protection for Women and Children, Anti-Bullying Child Protection Socialization. The program focuses more on women and children as the target, based on data from the Indonesian Child Protection Commission (KPAI) during 2018 there were 4,885 cases. The case of children dealing with the law ranks first, namely 1,434 cases, followed by

13 Cholisin. (2011). Pemberdayaan Masyarakat. Disampaikan Pada Gladi Manajemen Pemerintahan Desa Bagi Kepala Bagian/Kepala Urusan Hasil Pengisian Tahun 2011 Di Lingkungan Kabupaten Sleman, 19-20 Desember 2011, Pp. 19-20. 
cases related to family and child care as many as 857 cases. Then based on data released by the government - assisted by the United Nations Population Fund (UNFPA) in March 2017, the majority of Indonesian women have experienced sexual and physical violence. The results achieved during the 43 days of Community Services (KKN) in Bandungan Subdistrict, Bandungan District, Semarang Regency as a whole were the targets or targets of the program we carried out in which children and women were very enthusiastic and actively participated in follow the work program that has been implemented.

\section{E. Acknowledgments}

Authors would like to express the thakfullness to: Mr. Adiarso, S.TP, who has guided during the implementation of the KKN work program and also Mrs. Cahya Wulandari, S.H., M.Hum as a lecturer and supervisor who helped also gave us support. On this occasion, we would like to express our deepest gratitude to the Kormades (Village Student Coordinator) of the UNNES KKN Team for their policy in coordinating members so that all work programs can be carried out as well as for the Bandungan sub-district community for their participation in the work program that we have carried out. Do not forget to all those who have helped in the research and preparation of this article. We are fully aware of the limited capabilities that we have. Therefore, we expect constructive criticism and suggestions.

\section{F. Declaration of Conflicting Interests}

The authors state that there is no potential conflict of interest in the research, authorship, and / or publication / publication of this article.

\section{G. Funding}

Program of the community services and research funded by Authors it self as well as publication. Authors declare that there is no sponsorhip or any other parties funded the program.

\section{H. References}

Andhini, A.S.D., \& Arifin, R. (2019). Analisis Perlindungan Hukum Terhadap Tindak Kekerasan pada Anak di Indonesia. Ajudikasi: 
Jurnal Ilmu Hukum 3(1), 41-52. DOI: http://dx.doi.org/10.30656/ajudikasi.v3i1.992

Angga, A., \& Arifin, R. (2019). Penerapan Bantuan Hukum Bagi Masyarakat Kurang Mampu di Indonesia. DIVERSI: Jurnal Hukum 4(2), 218-236. DOI: https://doi.org/10.32503/diversi.v4i2.374

Arifin, R., \& Lestari, L.E. (2019). Penegakan dan Perlindungan Hak Asasi Manusia di Indonesia dalam Konteks Implementasi Sila Kemanusiaan yang Adil dan Beradab. Jurnal Komunikasi Hukum (JKH) 5(2), 12-25. DOI: http://dx.doi.org/10.23887/jkh.v5i2.16497

Arifin, R., Widyawati, A., Rasdi, R., Wicaksono, S. S., \& Maskur, M. A. (2019). Penguatan Kapasitas Hukum Bagi Orang Tua Siswa dan Guru di Desa Kalisegoro Semarang dalam Rangka Peningkatan Kesadaran Tanggungjawab Pendidikan Bersama (Sebuah Pengabdian Pendekatan Hak Asasi Manusia. Jurnal Pengabdian Hukum Indonesia (Indonesian Journal of Legal Community Engagement) JPHI, 1(2), 158-171. Retrieved from https://journal.unnes.ac.id/sju/index.php/JPHI/article/view/28637

Cholisin. (2011). Pemberdayaan Masyarakat. Disampaikan Pada Gladi Manajemen Pemerintahan Desa Bagi Kepala Bagian/Kepala Urusan Hasil Pengisian Tahun 2011 di Lingkungan Kabupaten Sleman, 1920 Desember 2011 , Pp. 19-20.

Dumasari. (2014). Dinamika Pengembangan Masyarakat Partisipasif. Yogayakarta: Pustaka Pelajar.

Hamid, U. (2019, 10 Maret). Bagaimana menguatkan perlindungan perempuan? Perkuat peran Komnas Perempuan. Dikutip pada tanggal 29 Agustus 2019 dari: https://theconversation.com/bagaimanamenguatkan-perlindungan-perempuan-perkuat-peran-komnasperempuan-112797.

Hilman, Y. A. \& Elok, P. N. (2018). Model Program Pemberdayaan Masyarakat Desa Berbasis Komunitas. Sosial Politik Humaniora 6(1): 45-67.

Juliana, R. \& Arifin, R. (2019). Anak dan Kejahatan (Faktor Penyebab dan Perlindungan Hukum). Jurnal Selat 6 (2), 225-234. DOI: https://doi.org/10.31629/selat.v6i2.1019

Kemala Dewi, M., \& Arifin, R. (2019). Emancipation and Legal Justice; Portrait of Women's Legal Protection In Indonesia. Jurnal Cita Hukum, 7(1), 101-114. DOI: https://doi.org/10.15408/jch.v7i1.10261

Muntamah, A.L., Latifiani, D., \& Arifin, R. (2019). Pernikahan Dini Di Indonesia: Faktor dan Peran Pemerintah (Perspektif Penegakan dan Perlindungan Hukum Bagi Anak). Widya Yuridika 2(1), 1-12. DOI: https://doi.org/10.31328/wy.v2i1.823 
Noor, M. (2011). Pemberdayaan Masyarakat. Jurnal Ilmiah CIVIS 1(2): 87 99.

Online, Redaksi (2018, 26 November). Sepanjang 2017, Kasus Kekerasan Terhadap Perempuan dan Anak Terus Meningkat. Dikutip pada $\begin{array}{llll}\text { tanggal } & 29 & \text { Agustus } & 2019\end{array}$ https://www.wartaekonomi.co.id/read165375/sepanjang-2017-kasuskekerasan-terhadap-perempuan-dan-anak-terus-meningkat.html.

Pemerintah Indonesia. (2010). Peraturan Menteri Negara Pemberdayaan Perempuan Dan Perlindungan Anak Republik Indonesia Nomor 13 Tahun 2010 Tentang Petunjuk Teknis Kabupaten/Kota Layak Anak di Desa/Kelurahan. Sekretariat Negara. Jakarta.

Peraturan Kementrian Negara Pemberdayaan Perempuan dan Perlindungan Anak Republik Indonesia Nomor 11 Tahun 2011 (Tentang Kebijakan/Pengembangan Kota Layak Anak).

Perdana, A., Holilulloh, M., Holilulloh, M. S., \& Nurmalisa, Y. (2013). Pengaruh Pelaksanaan Kuliah Kerja Nyata Terhadap Keterampilan Sosial Mahasiswa Program Studi PPKN. Jurnal Kultur Demokrasi, 1(7).

Puspitasari, D. C. (2015). Wirausaha Muda membangun Desa: Dinamika Partisipasi Pembangunan Desa. Jurnal Studi Pemuda. 4(2): 330-341.

Puspitasari, D.C. (2016). Wirausaha Sosial Muda Desa: Peran Strategis Pemberdayaan Masyarakat Desa.Makalah Seminar Nasional Universitas Negeri Lampug (UNILA), Lampung, 12 November 2016.

Rukminto, A. I. (2008). Intervensi Komunitas: Pengembangan Masyarakat Sebagai Upaya Pemberdayaan Masyarakat. Jakarta: PT Grafindo Persada.

Sanjaya, W. (2010). Strategi Pembelajaran Berorientasi Standar Proses Pendidikan. Jakarta: Kencana.

Setyaningrum, A., Arifin, R. (2019). 'Analisis Upaya Perlindungan dan Pemulihan Terhadap Korban Kekerasan dalam Rumah Tangga (KDRT) Khususnya Anak-Anak dan Perempuan'. JURNAL MUQODDIMAH: Jurnal Ilmu Sosial, Politik dan Hummaniora 3(1), 9-19. Retrieved from http://jurnal.umtapsel.ac.id/index.php/muqoddimah/article/view/677

Widyanuratikah, I., \& Puspita, R. (2019, 8 Januari). KPAI Terima Pengaduan 4.885 Kasus Anak Selama 2018. Dikutip pada tanggal 29 Agustus 2019 dari: https://www.republika.co.id/berita/nasional/umum/19/01/08/pl0dj1428 -kpai-terima-pengaduan-4885-kasus-anak-selama-2018. 
S. Setiawan, M.A. Saifunuha, J.L. Kautsar, \& C. Wulandari

Yulianti, Y. (2012). Analisis Partisipasi Masyarakat dalam Pelaksanaan Program Nasional Pemberdayaan Masyarakat (PNPM) Mandiri Perkotaan. Padang: Universitas Andalas.

Copyrights (C) 2019 by Auhtor(s). This work is licensed under a Creative Commons Attribution-NonCommercial-ShareAlike 4.0 International License. All writings published in this journal are personal views of the authors and do not represent the views of this journal and the author's affiliated institutions. 